\title{
Methicillin-resistant Staphylococcus aureus containing mecC in Swedish dairy cows
}

\author{
Helle Ericsson Unnerstad*, Björn Bengtsson, Margareta Horn af Rantzien and Stefan Börjesson
}

\begin{abstract}
Background: Hitherto, methicillin-resistant Staphylococcus aureus (MRSA) has not been detected in Swedish cattle.

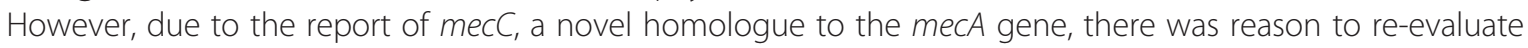
susceptibility results from strain collections of Staphylococcus aureus and test suspected isolates for the presence of mecC.

Findings: Bovine isolates of $S$. aureus with elevated minimum inhibitory concentrations of beta-lactams were retrospectively tested for presence of mecC. In four of the isolates mecC was detected.

Conclusion: In Sweden, this is the first finding of MRSA in cattle and the first detection of MRSA harbouring mecC of domestic animal origin. MRSA in animal populations has implications as a potential reservoir with risk for spread to humans. Occurrence of MRSA among Swedish cattle appears still very limited.
\end{abstract}

Keywords: MRSA, Staphylococcus aureus, mecC, Mastitis, Dairy cows

\section{Findings}

Methicillin-resistant Staphylococcus aureus (MRSA) first emerged as a problem in hospitals but is now also widely distributed in the community, although the prevalence varies among European countries [1]. In animal settings, MRSA has been an increasing problem for the last ten years, initially as the cause of clinical disease in companion animals and horses. It is now widely distributed in pig populations in many countries and has also been described in poultry and veal calves [2]. In most food-producing animals, MRSA rarely causes clinical disease, although there are reports of arthritis, dermatitis and sepsis in pigs [3]. In dairy cows, S. aureus is a common bacterial cause of mastitis and MRSA is known to cause mastitis as well [4]. Among food-producing animals, the MRSA lineage clonal complex (CC) 398 is clearly dominating. A reservoir in food-producing animals may constitute a risk for human health and can give a significant contribution to the burden of MRSA in human healthcare, at least in low prevalence countries [5]. In 2011 MRSA with a divergent mecA homologue, named mecC (formerly $m e c A_{\mathrm{LGA} 251}$ ), was detected in milk samples from dairy cows in the UK and human

\footnotetext{
* Correspondence: helle.unnerstad@sva.se

Department of Animal Health and Antimicrobial Strategies, National Veterinary Institute, Uppsala SE-751 89, Sweden
}

clinical samples in the UK, Denmark and Ireland [6,7]. The $m e c C$ has only $\sim 70 \%$ similarity with $m e c A$ and is not identified with conventional confirmatory methods [6].

Sweden is still a country with low prevalence of MRSA infections in humans and $<1 \%$ of invasive $S$. aureus isolates are MRSA [8]. Therefore, measures to prevent a situation where animals become a reservoir for MRSA are important. The situation in production animals in Sweden is still favourable and so far MRSA has only been detected in one pig herd, indicating a low prevalence also in the pig population [9].

In order to investigate the presence of MRSA in dairy cows in Sweden, penicillinase-producing S. aureus isolates originating from milk samples sent to the Mastitis Laboratory, National Veterinary Institute, Uppsala, Sweden for routine bacteriology were screened for MRSA phenotype in 2010-2011. For practical reasons penicillinase-negative isolates were not tested, since it was expected that the majority of MRSA-isolates produce penicillinase.

During the time period, 8757 submissions of milk samples from cows were received. Each submission constituted a variable number of milk samples from one farm, and samples from the same farm could have been submitted more than once. In $534(6 \%)$ of the submissions, at least one sample contained $S$. aureus and in 
207 submissions (2\%), penicillinase-producing S. aureus was detected in the routine testing using the "cloverleaf" method [10]. The samples emanated from dairy farms in different parts of Sweden but the MRSA-screening was performed anonymously and epidemiological information of individual samples, such as geographical origin, was not known. Samples most likely originated from cows with mastitis although clinical data on each cow were not available. During January to April 2010, all penicillinaseproducing isolates were tested for resistance to oxacillin and cefoxitin by microdilution using the VetMIC MRS panel (National Veterinary Institute, Uppsala, Sweden) following CLSI standard M31-A3 [11], but during the remaining period only one isolate per submission was tested. In total, this resulted in 311 penicillinase-producing isolates analysed by microdilution and seven of these were suspected of being MRSA due to elevated minimum inhibitory concentrations (MICs) of oxacillin and cefoxitin, but the $m e c A$ gene was not detected with polymerase chain reaction (PCR). When knowledge about the novel mecA homologue became available, our results were re-evaluated and all isolates with MICs of oxacillin (with $2 \% \mathrm{NaCl}$ ) and / or cefoxitin $\geq 4 \mathrm{mg} / \mathrm{L}$ (in total 58 isolates), were tested for the presence of mecA and $m e c C$ with PCR [6]. Four of these isolates were verified as MRSA carrying mecC.

The confirmed MRSA isolates were further characterized by spa-typing [12], multilocus sequence typing (MLST) [13], pulsed-field gel electrophoresis (PFGE) [14] and detection of the Panton Valentine leukocidine (PVL) toxin genes [15]. They were also tested for antimicrobial susceptibility to cephalothin, chloramphenicol, ciprofloxacin, clindamycin, erythromycin, fucidic acid, gentamicin, kanamycin, oxacillin, penicillin, tetracycline and trimethoprim by microdilution using the VetMIC GP-mo panel (National Veterinary Institute, Uppsala, Sweden) following CLSI standard M31-A3 [11] Three of the isolates, originating from milk samples collected in 2010, were of spa-type t524 (spa repeat succession 04-17) and ST130 (CC130) and had identical PFGE-patterns. One isolate, originating from a milk sample collected in 2011, was of spa-type t9111 (14-44-12-23-18-1717-17-23-24), ST425 (CC425) and showed a PFGE-pattern different from the other three isolates. The PVL-genes were not detected in any of the isolates. All four isolates were resistant to beta-lactams, but susceptible to all other antimicrobials tested. The isolates were confirmed to produce penicillinase which is noteworthy because, to our knowledge, penicillinase production has not been reported in isolates with $m e c C$ despite presence of the betalactamase gene blaZ [6].

As part of the surveillance of antimicrobial resistance in mastitis pathogens from dairy cows in Sweden, several studies have been performed during the last ten years without findings of MRSA. Isolates in these studies have been tested for antimicrobial susceptibility as described above. Results of susceptibility testing of 419 isolates of S. aureus from dairy cows since 2001 were available for re-evaluation. In this material, 39 isolates were subjected to testing for the presence of $m e c A$ and $m e c C$ with PCR, but MRSA was not detected.

In total, $730(311+419)$ isolates were available for investigation, but only four were confirmed to be MRSA indicating a low prevalence among dairy cows in Sweden, at least in association with mastitis. MRSA with $m e c C$ has also been identified in human clinical samples in Sweden [16]. Since the geographic origin of the bovine isolates is unknown it is not possible to investigate epidemiological links between isolates or links to human isolates of MRSA from Swedish healthcare. The Swedish bovine isolates belonged to the same MLST:s identified in bovine milk samples in the UK and in human samples from the UK, Denmark, Ireland and Germany $[6,7,17]$. However, none of the Swedish bovine isolates was of spa-type t843 (04-82-17-25-17-25-25-16-17), which appears to be common in other countries $[6,17,18]$. It has been suggested that MRSA CC130 might be bovine associated, but further studies are needed to establish if this truly is the case [6].

In conclusion, this is the first finding of MRSA in Swedish cattle, as well as the first detection of MRSA with $m e c C$ of domestic animal origin in Sweden. In addition, occurrence of MRSA among Swedish cattle appears still very limited.

\section{Competing interests}

The authors declare that they have no competing interests.

\section{Authors' contributions}

HEU participated in the design of the study and drafted the manuscript. BB participated in the design of the study and helped to draft the manuscript. MHR participated in the design of the study and carried out the susceptibility testing. SB participated in the design of the study, helped to draft the manuscript and carried out the molecular analyses. All authors read and approved the final manuscript.

\section{Acknowledgments}

This work was partly supported by the Swedish Board of Agriculture. Dr Mark A Holmes, Department of Veterinary Medicine, University of Cambridge, UK, is kindly acknowledged for providing a mecC positive control strain.

Received: 2 November 2012 Accepted: 28 January 2013 Published: 31 January 2013

\section{References}

1. Deurenberg $\mathrm{RH}$, Stobberingh EE: The evolution of Staphylococcus aureus. Infec Genet Evol 2008, 8:747-763.

2. Weese JS, Van Duijkeren E: Methicillin-resistant Staphylococcus aureus and Staphylococcus pseudintermedius in veterinary medicine. Vet Microbiol 2010, 140:418-429.

3. van der Wolf PJ, Rothkamp A, Junker K, De Neeling AJ: Staphylococcus aureus (MSSA) and MRSA (CC398) isolated from post-mortem samples from pigs. Vet Microbiol 2012, 158:136-141.

4. Vanderhaeghen W, Cerpentier T, Adriaensen C, Vicca J, Hermans K, Butaye P: Methicillin-resistant Staphylococcus aureus (MRSA) ST398 associated with 
clinical and subclinical mastitis in Belgian cows. Vet Microbio/ 2010, 144:166-171.

5. European Food Safety Authority: Scientific opinion of the panel on biological hazards on a request from the European Commission on assessment of the public health significance of meticillin resistant Staphylococcus aureus (MRSA) in animals and foods. The EFSA Journal. 2009, 993:1-73.

6. Garcia-Alvarez L, Holden TG, Lindsay H, Webb CR, Brown DFJ, Curran MD, Walpole E, Brooks K, Pickard DJ, Teale C, Parkhill J, Bentley SD, Edwards GF, Girvan EK, Kaerns AM, Pichon B, Hill RLR, Larsen AR, Skov RL, Peacock SJ, Maskell DJ, Holmes MA: Meticillin-resistant Staphylococcus aureus with a novel mecA homologue in human and bovine populations in the UK and Denmark: a descriptive study. Lancet Infect Dis 2011, 11:595-603.

7. Shore AC, Deasy EC, Slickers P, Brennan G, O'Connell B, Monecke S, Ehricht $\mathrm{R}$, Coleman DC: Detection of staphylococcal cassette chromosome mec type $\mathrm{XI}$ carrying highly divergent mecA, mecl, mecR1, blaZ, and ccr genes in human clinical isolates of clonal complex 130 methicillin-resistant Staphylococcus aureus. Antimicrob Agents Chemother 2011, 55:3765-3773.

8. European Center for Disease Prevention and Control: Antimicrobial resistance surveillance in Europe 2010. Sweden: ECDC, Stockholm; 2011. http://www. ecdc.europa.eu/en/publications/Publications/1111_SUR_AMR_data.pdf.pdf.

9. Ericsson Unnerstad $\mathrm{H}$, Lindberg M, Börjesson S, Grönlund Andersson U: Screening for methicillin-resistant Staphylococcus aureus (MRSA) in pigs and horses in Sweden [abstract]. In Proceedings of the 2nd ASM-ESCMID Conference on Methicillin-resistant Staphylococci in Animals: Veterinary and Public Health Implications: 8-11 September, 2011. Washington, DC; 2011:47.

10. Bryan LE, Godfrey AJ: Beta-lactam antibiotics: mode of action and bacterial resistance. In Antibiotics in laboratory medicine. Edited by Baltimore LV. USA: Williams \& Wilkins; 1991:648.

11. Clinical and Laboratory Standards Institute: Performance standards for antimicrobial disk and dilution susceptibility tests for bacteria isolated from animals; approved standard. 3rd edition. Wayne, PA: M31-A3. CLSI; 2008.

12. Harmsen D, Claus H, Witte W, Rothganger J, Turnwald D, Vogel U: Typing of methicillin-resistant Staphylococcus aureus in a university hospital setting by using novel software for spa repeat determination and database management. J Clin Microbiol 2003, 41:5442-5448.

13. Enright MC, Day NP, Davies CE, Peacock SJ, Spratt BG: Multilocus sequence typing for characterization of methicillin-resistant and methicillinsusceptible clones of Staphylococcus aureus. J Clin Microbiol 2000, 38:1008-1015

14. Murchan SM, Kaufmann E, Deplano A, De Ryck R, Struelens M, Zinn CE, Fussing V, Salmenlinna S, Vuopio-Varkila J, El Solh N, Cuny C, Witte W, Tassios PT, Legakis N, Leeuwen W, Van Belkum A, Vindel A, Laconcha I, Garaizar J, Haeggman S, Olsson-Liljequist B, Ransjo U, Coombes G, Cookson B: Harmonization of pulsed-field gel electrophoresis protocols for epidemiological typing of strains of methicillin-resistant Staphylococcus aureus: a single approach developed by consensus in 10 European laboratories and its application for tracing the spread of related strains. J Clin Microbiol 2003, 41:1574-1585.

15. Francois $P$, Renzi $G$, Pittet $D$, Bento $M$, Lew $D$, Harbarth $S$, Vaudaux $P$, Schrenzel J: A novel multiplex real-time PCR assay for rapid typing of major staphylococcal cassette chromosome mec elements. J Clin Microbiol 2004, 42:3309-3312.

16. Swedish Institute for Communicable Disease Control: SWEDRES 2011. A report on Swedish antibiotic utilisation and resistance in human medicine. 2012. http://www.smittskyddsinstitutet.se/upload/Publikationer/SWEDRESSVARM-2011_2012-15-3.pdf.

17. Cuny C, Layer F, Strommenger B, Witte W: Rare occurrence of methicillinresistant Staphylococcus aureus $\mathrm{CC} 130$ with a novel mecA homologue in humans in Germany. PLoS One 2011, 6:e24360.

18. Kriegeskorte A, Ballhausen B, Idelevich EA, Kock R, Friedrich AW, Karch $H$, Peters G, Becker K: Human MRSA isolates with novel genetic homolog Germany. Emerg Infect Dis 2012, 18:1016-1018.

doi:10.1186/1751-0147-55-6

Cite this article as: Unnerstad et al:: Methicillin-resistant Staphylococcus aureus containing mecC in Swedish dairy cows. Acta Veterinaria Scandinavica 2013 55:6.

\section{Submit your next manuscript to BioMed Central and take full advantage of:}

- Convenient online submission

- Thorough peer review

- No space constraints or color figure charges

- Immediate publication on acceptance

- Inclusion in PubMed, CAS, Scopus and Google Scholar

- Research which is freely available for redistribution

Submit your manuscript at www.biomedcentral.com/submit
() Biomed Central 